\title{
Effect of Condensed Tannin Feeding on Serum Biochemical Profile and Faecal Egg Count in Nellore Brown Ewes
}

\author{
K. Sireesha ${ }^{1 *}$, Ch. Venkata Seshaiah ${ }^{2}$, K. Sudhakar ${ }^{3}$, D. S. Kumar ${ }^{4}$ and R.Vinoo ${ }^{5}$ \\ ${ }^{1}$ Department of Livestock Production Management, ${ }^{2}$ Department of LFC, \\ ${ }^{3}$ Department of LPM, ${ }^{4}$ Department of ANN, ${ }^{5}$ Department of AGB, NTR College of \\ Veterinary Science, Sri Venkateswara Veterinary University, Gannavaram- 521102, \\ Andhra Pradesh, India \\ *Corresponding author
}

\section{Keywords}

Complete feed, Condensed tannin, Leaf Meal Mixture, Haematology, serum biochemical profile, Faecal egg count

\section{Article Info}

\section{Accepted:}

12 April 2021

Available Online: 10 May 2021

\section{A B S T R A C T}

Present study was conducted to assess the effect of feeding condensed tannins supplemented through leaf meal mixture on haematology, serum biochemical profile and faecal egg count in Nellore brown ewes. 18 Nellore brown ewes of similar age and body weight (3-3.5 yrs, $25.03 \pm 1.52 \mathrm{~kg}$ ) were selected and randomly divided into three groups Negative Control (dewormed), Control (without deworming), Treatment group (T) of six animals in each group. Both control groups were fed with complete feed, while treatment group ewes were fed with complete feed in which part of roughage was replaced with tanniferous leaf meal mixture to get $3 \%$ condensed tannin level in the diet and the experiment was conducted for the period of 120 days. Blood and serum samples were collected periodically (30 days interval) and analysed for haematology and serum biochemical profile. The mean $\mathrm{Hb}(\mathrm{g} / \mathrm{dl})$ levels were significantly $(\mathrm{P}<0.05)$ low in $\mathrm{C}$ group compared to other groups and significantly $(\mathrm{P}<0.05)$ high in $\mathrm{T}, \mathrm{NC}$ groups. The mean $\mathrm{PCV}(\%)$ values were significantly $(\mathrm{P}<0.05)$ low in $\mathrm{C}$ group compared to other groups. The mean serum urea $(\mathrm{mg} / \mathrm{dl})$ levels in the treatment group of lambs were found to be significantly $(\mathrm{P}<0.05)$ lower compared to both control groups. The fecal egg count was significantly $(\mathrm{P}<0.05)$ low in treatment group. The results of the present study revealed that inclusion of Condensed tannin at $3 \%$ level in the diets of sheep does not cause any effect on health of the animal and also decreases the fecal egg count.

\section{Introduction}

Infestation of parasites particularly that of gastrointestinal (GI) tract like helminthes has been regarded as one of the major constraints for animal production as they interfere with nutrient bioavailability for production purposes and may create clinical conditions 
leading to productive and economic losses (Githigia et al., 2001). Control strategy for helminthic infection relies on the repeated use of dewormers which results in anti helminthic resistance. In this regard, tannins predominantly condensed tannin (CT) has emerged as a potential contender as natural anthelmintics (Iqbal et al., 2007; Pathak et al., 2013). It has proved its worth for the purpose as evident by several studies claiming reduction in faecal egg count (FEC) and worm load in host animal species (Gujja et al., 2013). Many of Indian tree leaves are rich source of plant secondary metabolites (PSMs) including tannin and also constitute the natural component of small ruminants diets (Bhatta $e t$ al., 2005). Due to high level of CT in their leaves, they have displayed their anthelmintic effect with elevation in nutritional and antioxidant status of farm animal models (Dutta et al., 2012; Dey and De, 2014).

Keeping this in view, present study was planned to investigate the effect of feeding CT through LMM (leaf meal mixture) on haematology, serum biochemical profile and fecal egg count in Nellore brown ewes.

\section{Materials and Methods}

Present study was carried out at Livestock Farm Complex, NTR College of Veterinary Science, Gannavaram, Andhra Pradesh during the period from 2019 to 2020 .

\section{Experimental Animals and Feeding}

A total of 18 Nellore brown ewes aged 3-3.5 years with a mean live weight of $25.03 \pm 1.52$ $\mathrm{kg}$, tested positive for Haemonchus infestation were selected and randomly divided into three groups of 6 animals each in a completely randomized design.

Group I ewes (Negative control-NC) were fed with conventional complete feed containing concentrate and roughage (ground nut straw) in the ratio of 50:50 and dewormed using Albendazole suspension @ 10mg/kg body weight. Group II ewes were positive control (C) fed with conventional feed and were not dewormed throughout the experiment Group III animals were served as treatment group (T) they were fed with complete feed in which part of groundnut straw was replaced with dried and grounded tree leaves mixture of $L$. leucocephala, $F$. Benghalensis and $P$. guajava at 40:40:20 proportions so as to bring the condensed tannin (CT) levels 3\% per cent of diet.

All the animals were kept under uniform managemental conditions by housing them in a well-ventilated shed with facilities for uniform feeding and watering.

\section{Collection of Blood}

Blood from all experimental animals were collected early in the morning before feeding, by jugular vein puncture.

About $4 \mathrm{ml}$ of whole blood was collected from every animal in EDTA vaccutainer for analysing haematotological profile and another $4 \mathrm{ml}$ of blood was collected in another vaccutainer in which clot activator is there to hasten the clotting and allowed for clotting. After clotting, the tubes were centrifuged to collect sera. The collected sera samples were stored in deep freezer for further analysis.

\section{Haematological Parameters}

Haemoglobin $(\mathrm{Hb})$ and PCV were analyzed using automatic MIND RAY haemoanalyser

\section{Biochemical parameters}

All the biochemical parameters were estimated by using Erba diagnostic kits (TRANSASIA BIO -MEDICALS LTD). 


\section{Fecal egg count}

Faecal samples were collected (per rectum) from experimental animals for every 15 days. Each sample was put in a plastic bag bearing a number of corresponding tag number of the animal. After collection, the samples were taken to the laboratory and egg counts were made using the modified McMaster technique (Roepstorff and Nansen, 1998).

\section{Statistical Analysis}

The results obtained were subjected to analysis of variance using SPSS 25.0 software and treatment means were ranked using Duncan's multiple range tests. The degree of freedom of the treatments was portioned into orthogonal polynomial, depicting linear and quadratic trends associated with increasing levels of CT supplementation. Significance was declared at $\mathrm{P}<0.05$ unless otherwise stated. All the statistical procedures were done as per Snedecor and Cochran (1994).

\section{Results and Discussion}

\section{Effect of CT feeding on hematological parameters}

Blood samples were collected from sheep on day one of the experiment and thereafter at 30 days intervals for a period of 120 days. The blood was used for estimation of hematological parameters viz., Hemoglobin $(\mathrm{Hb})$ level and packed cell volume (PCV).

\section{Effect on hemoglobin (g/dl) and PCV (\%)}

The mean $\mathrm{Hb}$ levels (g/dl) and PCV (\%) of ewes under different experimental groups were presented in Table 1 . The $\mathrm{Hb}(\mathrm{g} / \mathrm{dl})$ values as well as PCV (\%) values were found to decrease gradually from beginning to the end of experiment in the control group and this decrease could be attributed to increased parasitic burden. In other groups, there was no significant change in the $\mathrm{Hb}(\mathrm{g} / \mathrm{dl})$ and $\mathrm{PCV}$ (\%) values with the time. The mean PCV (\%) values were significantly $(\mathrm{P}<0.05)$ low in $\mathrm{C}$ group compared to other groups, while the difference was not significant $(\mathrm{P}<0.05)$ among other groups.

Therefore, feeding of condensed tannin (CT) reduced the parasitic burden which results no significant change in the $\mathrm{Hb}(\mathrm{g} / \mathrm{dl})$ and $\mathrm{PCV}$ (\%) values in the sheep. Similar findings with respect to $\mathrm{Hb}(\mathrm{g} / \mathrm{dl})$ and $\mathrm{PCV}(\%)$ were reported by Pathak et al., (2013) in sheep fed CT through leaf meal mixture.

Parallel to the present findings, Moore et al., (2008) observed that feeding of CT up to $4 \%$ in the diet has no adverse effect on hematological parameters during the 120 days of feeding experiment. However, it was reported that supplementation of $\mathrm{CT}$ at $6 \%$ level in goats decreased $(\mathrm{P}<0.05) \mathrm{PCV}(\%)$ and $\mathrm{Hb}(\mathrm{g} / \mathrm{dl})$ level due to binding of the tannin especially with Fe (Olafadehan, 2011).

Based on the results obtained in the present study, the anthelminthic effect of CT may be responsible (Hoste et al., 2012) for optimum $\mathrm{PCV}(\%)$ and $\mathrm{Hb}(\mathrm{g} / \mathrm{dl})$ levels in treatment group compared to the control sheep.

\section{Effect of CT feeding on serum biochemical parameters}

Different biochemical parameters studied during the experiment were serum glucose, serum proteins (Total protein, Albumin, Globulin \& AG Ratio), calcium, phosphorous, copper, total cholesterol, serum creatinine, serum urea, SGOT and SGPT.

\section{Effect on liver function tests}

The mean serum total protein, albumin and globulin $(\mathrm{g} / \mathrm{dl})$ levels and AG ratio values for 
different experimental groups at different periods of the experiment were presented in Table 2. The mean serum total protein, serum albumin and globulin $(\mathrm{g} / \mathrm{dl})$ values at the end of the experiment were significantly $(\mathrm{P}<0.05)$ lower in control group compared to other groups, while the difference was not significant among other groups. $\mathrm{A} / \mathrm{G}$ ratio in control groups was significantly $(\mathrm{P}<0.05)$ higher when compared to treatment groups. Among the treatment groups, the $\mathrm{A} / \mathrm{G}$ ratio of $\mathrm{T}$ group was found to be significantly ( $\mathrm{P}<0.05)$ lower. Ahmed et al., (1990) also reported a decrease in total protein, albumin and an increase in Y-globulin (g/dl) levels in $H$. contortus infected sheep. It is possible to link the decreased level of total protein and albumin $(\mathrm{g} / \mathrm{dl})$ in infected control group which may occurs as a result of abomasal haemorrhage caused by $H$. contortus. It is attributable to the loss of serum proteins into the gut and the subsequent impaired synthesis of albumin (Sharma et al., 2001) as a result of acute phase response associated with elevated level of globulin (Murata et al., 2004).

However, the elevated globulin (g/dl) level in CT fed group may be due to indirect effect of $\mathrm{CT}$ to synthesize more immunoglobulins against $H$. contortus. Similar findings were reported by Dubey et al., (2007) in goats fed with tanniferous tree leaves.

\section{Effect on liver enzymes}

No significant difference was observed among different groups with respect to SGOT and SGPT (Table 3). Present results were in agreement with the findings of Pathak et al., (2013) in sheep and Olafadehan (2011) in goats fed with tanniferous forages.

The non significant difference in serum enzyme levels between treatment and control groups in the present study indicated that up to $3 \%$ level of CT feeding does not cause any damage to the internal organs like kidney and liver.

\section{Effect on serum biochemical profile}

The difference in mean serum glucose $(\mathrm{mg} / \mathrm{dl})$ values among the experimental groups was not statistically significant $(\mathrm{P}<0.05)$ and were found to be within the normal physiological range suggested for sheep (Boyd, 1984). The present results were consistent with the findings of Pathalk et al., (2013) and Cenci et al., (2007) who reported no significant difference in serum glucose $(\mathrm{mg} / \mathrm{dl})$ values in treatment and control groups.

Contrary to the present findings Wang et al., (1996b) reported lower plasma glucose $(\mathrm{mg} / \mathrm{dl})$ level in lactating ewes grazed on tanniferous Lotus corniculatus pasture, probably due to increased uptake of glucose from blood for milk lactose synthesis.

The serum cholesterol $(\mathrm{mg} / \mathrm{dl})$ values in the present study (Table 4) did not show any significant difference $(\mathrm{P}<0.05)$ among all the study groups. Similar results were reported by pathak et al., (2013) for serum cholesterol $(\mathrm{mg} / \mathrm{dl})$ in $H$. Contortus infected sheep fed with CT through leaf meal mixture. Similar to the present study Olafadehan (2011) reported no significant change in serum cholesterol (mg/dl) level in Red Sokoto goats fed tanninrich Pterocarpus erinaceus forage diets corroborated with present findings.

The range of creatinine $(\mathrm{mg} / \mathrm{dl})$ values reported in the present study was parallel with the findings of Pathak et al., (2013) who reported creatinine $(\mathrm{mg} / \mathrm{dl})$ values from $0.94 \pm 0.07$ to $1.11 \pm 0.09$ with no significant difference between treatment and control in sheep. Similar results were reported by Olafadehan et al., (2014) in goats fed diets containing varying ratios of tanniferous forage (Ficus polita). 
Table.1 Effect of condensed tannin feeding on haemoglobin concentration $(\mathrm{g} / \mathrm{dl})$ and packed cell volume (\%) in ewes

\begin{tabular}{|c|c|c|c|}
\hline Treatment & \multicolumn{1}{|c|}{ Day 1 } & 120 Day & Mean \\
\hline \multicolumn{4}{|c|}{ Haemoglobin concentration $(\mathbf{g} / \mathbf{d l})$} \\
\hline NC & $9.78 \pm 0.32$ & $9.18 \pm 0.30^{\mathrm{b}}$ & $9.39 \pm 0.14^{\mathrm{b}}$ \\
\hline $\mathbf{C}$ & $8.6 \pm 0.24$ & $6.82 \pm 0.13^{\mathrm{a}}$ & $7.64 \pm 0.14^{\mathrm{a}}$ \\
\hline $\mathbf{T}$ & $9.87 \pm 0.33$ & $9.58 \pm 0.51^{\mathrm{b}}$ & $9.55 \pm 0.19^{\mathrm{b}}$ \\
\hline \multicolumn{3}{|c|}{ Packed cell volume (\%) } \\
\hline NC & $40.32 \pm 0.37$ & $40.59 \pm 0.40^{\mathrm{bc}}$ & $39.89 \pm 0.23^{\mathrm{b}}$ \\
\hline $\mathbf{C}$ & $41.09 \pm 0.75$ & $29.00 \pm 0.55^{\mathrm{a}}$ & $35.07 \pm 0.86^{\mathrm{a}}$ \\
\hline $\mathbf{T}$ & $40.37 \pm 0.39$ & $40.90 \pm 0.23^{\mathrm{bc}}$ & $41.09 \pm 0.20^{\mathrm{b}}$ \\
\hline
\end{tabular}

abc means with different superscripts with in a column differ significantly $(\mathrm{P}<0.05)$

*NC: Negative control, C: Control, T: Treatment

Table.2 Effect of condensed tannin feeding on serum total protein, albumin, serum globulin and $\mathrm{AG}$ ratio

\begin{tabular}{|c|c|c|c|}
\hline Treatment & Day 1 & 120 Day & Mean \\
\hline NC & $5.8 \pm 0.10$ & $6.19 \pm 0.08^{\mathrm{b}}$ & $6.03 \pm 0.04^{\mathrm{b}}$ \\
\hline $\mathbf{C}$ & $5.52 \pm 0.15$ & $4.98 \pm 0.04^{\mathrm{a}}$ & $5.20 \pm 0.05^{\mathrm{a}}$ \\
\hline $\mathbf{T}$ & $5.8 \pm 0.18$ & $6.37 \pm 0.15^{\mathrm{b}}$ & $6.06 \pm 0.08^{\mathrm{b}}$ \\
\hline & \multicolumn{3}{|c|}{ Serum total protein $(\mathbf{g} / \mathbf{d l})$} \\
\hline $\mathbf{N C}$ & $2.63 \pm 0.05$ & $3.09 \pm 0.13^{\mathrm{b}}$ & $2.88 \pm 0.05^{\mathrm{b}}$ \\
\hline $\mathbf{C}$ & $2.61 \pm 0.09$ & $2.49 \pm 0.15^{\mathrm{a}}$ & $2.5 \pm 0.05^{\mathrm{a}}$ \\
\hline $\mathbf{T}$ & $2.77 \pm 0.08$ & $2.50 \pm 0.09^{\mathrm{a}}$ & $2.72 \pm 0.04^{\mathrm{b}}$ \\
\hline & \multicolumn{3}{|c|}{ Serum globulin $(\mathbf{g} / \mathbf{d l})$} \\
\hline $\mathbf{N C}$ & $3.17 \pm 0.14$ & $3.11 \pm 0.16^{\mathrm{b}}$ & $3.16 \pm 0.05^{\mathrm{b}}$ \\
\hline $\mathbf{C}$ & $2.92 \pm 0.09$ & $2.50 \pm 0.13^{\mathrm{a}}$ & $2.70 \pm 0.05^{\mathrm{a}}$ \\
\hline $\mathbf{T}$ & $3.03 \pm 0.12$ & $3.87 \pm 0.13^{\mathrm{c}}$ & $3.34 \pm 0.08^{\mathrm{b}}$ \\
\hline & & $\mathbf{A G}$ ratio \\
\hline $\mathbf{N C}$ & $0.84 \pm 0.05$ & $1.02 \pm 0.08$ & $0.92 \pm 0.03^{\mathrm{b}}$ \\
\hline $\mathbf{C}$ & $0.9 \pm 0.04$ & $1.03 \pm 0.12$ & $0.94 \pm 0.04^{\mathrm{b}}$ \\
\hline $\mathbf{T}$ & $0.92 \pm 0.04$ & $0.84 \pm 0.04$ & $0.83 \pm 0.02^{\mathrm{a}}$ \\
\hline
\end{tabular}

abc means with different superscripts with in a column differ significantly $(\mathrm{P}<0.05)$

Table.3 Effect of condensed tannin feeding on liver enzymes

\begin{tabular}{|c|c|c|c|}
\hline Treatment & Day 1 & 120 Day & Mean \\
\hline & \multicolumn{3}{|c|}{ SGOT (IU/L) } \\
\hline NC & $55.28 \pm 2.77$ & $73.89 \pm 1.03$ & $64.10 \pm 1.53$ \\
\hline C & $50.42 \pm 3.21$ & $72.64 \pm 1.95$ & $59.50 \pm 1.85$ \\
\hline T & $57.36 \pm 1.79$ & $71.93 \pm 1.20$ & $62.79 \pm 1.24$ \\
\hline & \multicolumn{3}{|c|}{ SGPT (IU/L) } \\
\hline NC & $23.17 \pm 0.86$ & $28.54 \pm 0.41$ & $26.98 \pm 0.46$ \\
\hline C & $25.15 \pm 1.42$ & $28.74 \pm 0.54$ & $27.75 \pm 0.46$ \\
\hline T & $24.66 \pm 0.75$ & $29.63 \pm 0.31$ & $28.16 \pm 0.41$ \\
\hline
\end{tabular}


Table.4 Effect of condensed tannin feeding on serum biochemical profile in ewes

\begin{tabular}{|c|c|c|c|}
\hline Treatment & Day 1 & 120 Day & Mean \\
\hline & \multicolumn{3}{|c|}{ Serum creatinine $(\mathrm{mg} / \mathrm{dl})$} \\
\hline $\mathrm{NC}$ & $0.85 \pm 0.03$ & $1.21 \pm 0.03$ & $0.97 \pm 0.04$ \\
\hline $\mathbf{C}$ & $0.81 \pm 0.02$ & $1.30 \pm 0.09$ & $1.00 \pm 0.04$ \\
\hline \multirow[t]{2}{*}{$\mathbf{T}$} & $0.87 \pm 0.04$ & $1.30 \pm 0.03$ & $1.03 \pm 0.04$ \\
\hline & \multicolumn{3}{|c|}{ Serum urea $(\mathrm{mg} / \mathrm{dl})$} \\
\hline NC & $41.76 \pm 0.22$ & $40.25 \pm 0.40^{\mathrm{b}}$ & $40.65 \pm 0.15^{\mathrm{b}}$ \\
\hline $\mathbf{C}$ & $42.28 \pm 0.20$ & $42.77 \pm 0.28 \mathrm{c}$ & $42.24 \pm 0.11^{\mathrm{b}}$ \\
\hline \multirow[t]{2}{*}{$\mathbf{T}$} & $42.02 \pm 0.29$ & $28.30 \pm 0.31^{\mathrm{a}}$ & $34.49 \pm 1.00^{\mathrm{a}}$ \\
\hline & \multicolumn{3}{|c|}{ Serum glucose $(\mathbf{m g} / \mathbf{d l})$} \\
\hline NC & $51.56 \pm 0.90$ & $54.06 \pm 0.76$ & $52.83 \pm 0.38$ \\
\hline C & $47.24 \pm 1.90$ & $47.02 \pm 1.24$ & $47.82 \pm 0.71$ \\
\hline $\mathbf{T}$ & $49.26 \pm 1.53$ & $51.40 \pm 0.87$ & $50.39 \pm 0.58$ \\
\hline \multicolumn{4}{|c|}{ Serum cholesterol (mg/dl) } \\
\hline $\mathrm{NC}$ & $56.73 \pm 1.75$ & $63.64 \pm 0.98$ & $60.34 \pm 1.09$ \\
\hline $\mathbf{C}$ & $63.25 \pm 1.11$ & $60.77 \pm 0.95$ & $60.85 \pm 1.17$ \\
\hline $\mathbf{T}$ & $59.54 \pm 4.04$ & $65.88 \pm 1.56$ & $61.12 \pm 1.04$ \\
\hline
\end{tabular}

Table.5 Effect of condensed tannin feeding on serum mineral profile in ewes

\begin{tabular}{|c|c|c|c|}
\hline Treatment & Day 1 & $\begin{array}{c}\text { 120 Day } \\
\text { Serum calcium }(\mathbf{m g} / \mathbf{d l})\end{array}$ \\
\hline & \multicolumn{3}{|c|}{ Mean } \\
\hline $\mathbf{N C}$ & $10.18 \pm 0.23$ & $10.23 \pm 0.22$ & $10.16 \pm 0.13$ \\
\hline $\mathbf{C}$ & $10.16 \pm 0.19$ & $10.63 \pm 0.25$ & $10.47 \pm 0.15$ \\
\hline $\mathbf{T}$ & $10.09 \pm 0.23$ & $9.80 \pm 0.47$ & $10.20 \pm 0.15$ \\
\hline \multicolumn{4}{|c|}{ Serum phosphorous (mg/dl) } \\
\hline $\mathbf{N C}$ & $5.27 \pm 0.06$ & $5.14 \pm 0.14$ & $5.29 \pm 0.04$ \\
\hline $\mathbf{C}$ & $5.35 \pm 0.10$ & $5.68 \pm 0.19$ & $5.41 \pm 0.05$ \\
\hline $\mathbf{T}$ & $5.29 \pm 0.011$ & $5.57 \pm 0.16$ & $5.48 \pm 0.07$ \\
\hline \multicolumn{4}{|c|}{ Serum copper $(\mathbf{m g} / \mathbf{d l})$} \\
\hline $\mathbf{N C}$ & $0.53 \pm 0.01$ & $0.41 \pm 0.04$ & $0.50 \pm 0.01$ \\
\hline $\mathbf{C}$ & $0.59 \pm 0.07$ & $0.55 \pm 0.01$ & $0.56 \pm 0.02$ \\
\hline $\mathbf{T}$ & $0.52 \pm 0.05$ & $0.46 \pm 0.01$ & $0.49 \pm 0.02$ \\
\hline
\end{tabular}

${ }^{a b c}$ means with different superscripts with in a column differ significantly $(\mathrm{P}<0.05)$ 
Table.6 Effect of condensed tannin feeding on faecal egg count

\begin{tabular}{|c|c|c|c|c|c|c|c|c|c|}
\hline & \multicolumn{9}{|c|}{ Fortnight Intervals } \\
\hline Treatment & Day 1 & I & II & III & IV & V & VI & VII & VIII \\
\hline NC & 425.00 & 350.00 & 425.00 & 575.00 & 758.33 & 200.00 & 366.67 & 583.33 & 783.33 \\
& $\pm 58.81^{\mathrm{a}}$ & $\pm 51.64^{\mathrm{a}}$ & $\pm 38.19^{\mathrm{a}}$ & $\pm 58.81^{\mathrm{a}}$ & $\pm 66.35^{\mathrm{a}}$ & $\pm 22.36^{\mathrm{a}}$ & $\pm 24.72^{\mathrm{a}}$ & $\pm 44.10^{\mathrm{a}}$ & $\pm 62.80^{\mathrm{b}}$ \\
\hline C & $2441.67 \pm 10$ & $2716.67 \pm 14$ & $2883.33 \pm 13$ & $2850.00 \pm 3$ & 3783.33 & $3916.67 \pm 11$ & $3866.67 \pm 10$ & $4316.67 \pm 8$ & $4533.33 \pm 8$ \\
& $0.35^{\mathrm{b}}$ & $8.16^{\mathrm{c}}$ & $2.71^{\mathrm{c}}$ & $4.16^{\mathrm{d}}$ & $\pm 89.47^{\mathrm{d}}$ & $9.49^{\mathrm{d}}$ & $2.20^{\mathrm{d}}$ & $4.58^{\mathrm{c}}$ & $4.33^{\mathrm{c}}$ \\
\hline T & $2500.00 \pm 14$ & $2300.00 \pm 11$ & $1983.33 \pm 10$ & $1233.33 \pm 7$ & 1050.00 & 866.67 & 600.00 & 466.67 & 350.00 \\
& $3.76^{\mathrm{b}}$ & $5.47^{\mathrm{b}}$ & $7.75^{\mathrm{b}}$ & $1.49^{\mathrm{b}}$ & $\pm 42.82^{\mathrm{b}}$ & $\pm 76.01^{\mathrm{b}}$ & $\pm 68.31^{\mathrm{b}}$ & $\pm 80.28^{\mathrm{a}}$ & $\pm 34.16^{\mathrm{a}}$ \\
\hline
\end{tabular}

${ }^{\text {abc }}$ means with different superscripts with in a column differ significantly $(\mathrm{P}<0.05)$ 
The insignificant effect of feeding of tannins on creatinine levels in the present study might be due to absence of wasting or catabolism of muscle tissues (Olafadehan 2011).

Serum urea $(\mathrm{mg} / \mathrm{dl})$ level is an indicator of protein degradation in rumen. The mean urea concentrations in condensed tannin fed groups were found to be significantly $(\mathrm{P}<0.05)$ lower compared to the control groups. Serum urea $(\mathrm{mg} / \mathrm{dl})$ levels in ewes were ranged from $42.24 \pm 0.11$ in control group to $34.49 \pm 1.00$ in T group. Pan and Maitra (1992) also observed lower (29.48 vs. $36.94 \mathrm{mg} / \mathrm{dl})$ blood urea levels in sheep with and without CT supplemented diets.

\section{Effect on serum mineral profile}

The serum $\mathrm{Ca}, \mathrm{P}$ and $\mathrm{Cu}(\mathrm{mg} / \mathrm{dl})$ values (Table $5)$ did not differ significantly $(\mathrm{P}<0.05)$ among different dietary treatments and the values were found to be within the normal physiological range for sheep (Boyd, 1984). Similar findings of non significant difference in $\mathrm{Ca}$ and $\mathrm{P}(\mathrm{mg} / \mathrm{dl})$ values were reported by Pathak et al., (2013) in sheep supplemented with CT through leaf meal mixture.

\section{Effect on fecal egg count}

The faecal egg counts (Table 6) on day 120 were reduced by $86.0 \%$ in $\mathrm{T}$ group, when compared with the day one faecal egg counts of the experiment. Similar to the present findings, Cenci et al., (2007) reported that faecal egg count (FEC), was significantly reduced in lambs fed with tanniferous herbage (Acácia negra) within eight weeks of the experiment. Similarly Moore et al., (2008) and Shaik et al., (2006) also observed that feeding of Sericea lespedeza hay and L. cuneata hay, respectively significantly reduced the FEC in goats compared to control animals. Several earlier studies were also demonstrated the anthelminthic effect of tanniferous herbage in sheep and goat (Gregory et al., 2017; Manolaraki et al., 2010).

Several workers reported repressed female nematode reproductive activity as another direct effect of CT on GIN, which explained the decrease in faecal egg count (FEC) measured in several trials where feeding experiments were conducted with tannin-rich forages (Ahmed et al., 2010; Heckendorn 2007). An indirect effect of tannins by a stimulation of the local immune response, due to their protective effect for proteins against ruminal degradation (Mangan, 1988) has also been evoked as one option to explain their action on nematodes.

CT supplementation from various forages and tree have been found to reduce the level of GI parasitic infestation in cattle (Novobilsky et al., 2011), buffalo (Netpana et al., 2001), goat (Joshi et al., 2011) and sheep (Cresswell et al., 2004).

The present study concluded that dietary supplementation of $\mathrm{CT}$ at $3 \%$ effectively reduce the faecal egg count in sheep, thereby reduce the use of chemical dewormers and provides an alternative path for organic sheep production.

\section{Acknowledgements}

The authors are immensely grateful to Sri Venkateswara Veterinary University, Tirupati and Livestock Farm Complex, Gannavaram for provision of funds and allowing for conducting of research.

\section{References}

Ahmad, A., Anwar-ul-Hassan, C., Anwar-ul-Haq, A., Majeed, M. A. 1990. Serum proteinogram of lambs experimentally induced Haemonchus contortus infection. Veterinary Archives, 60:195-200.

Ahmed, M., Laing, M. D. and Nsahlai, I. V. 2010. 
In vivo effect of selected medicinal plants against gastrointestinal nematodes of sheep. Tropical Animal Health and Production, 46: 411-417.

Bhatta, R., Vaithiyanathan, S., Singh, N. P., Shinde, A. K. and Verma, D. L. 2005. Effect of feeding tree leaves as supplements on the nutrient digestion and rumen fermentation pattern in sheep grazing on semi-arid range of India-1. Small Ruminant Research, 60: 273-280.

Boyd, J. W. 1984. The interpretation of serum biochemistry test results in domestic animals. In: Veterinary Clinical Pathology, Veterinary Practice Publishing, 13 (2):714.

Cenci, F. B., Louvandini, H., McManus, C. M., Dell'Porto, A., Costa, D. M., Araújo, S. C., Minho, A. P. and Abdalla, A. L. 2007. Effects of Condensed Tannin from Acacia Mearnsii on Sheep Infected Naturally with Gastrointestinal Helminthes. Veterinary Parasitology, 144(1-2):132-37.

Cresswell, K. J., Teleni, E. and Copeman, D. B. 2004. The potential anthelmentic effect of Callindracalothyrsus in lambs. Asia Pacific Journal of Clinical Nutrition, 13 (Suppl): S90.

Dey, A. and De, P. S. 2014. Influence of condensed tannins from Ficus benghalensis leaves on feed utilization, milk production and antioxidant status of crossbred cows. Asian Australasian Journal of Animal Sciences, 27: 342-48.

Dubey, M. 2007. Strategic use of tanniferous tree leaves on nutrient utilization, growth and GI parasites in goats. M.V.Sc. Thesis. Deemed University, IVRI, Izatnagar, UP, India.

Dutta, N., Dubey, M., Banerjee, P. S., Pattanaik, A. K., Sharma, K., Kumar, P. and Narang, A. 2012. Effect of supplementing tanniferous tree leaves mixture on immune response and GI nematodes in kids. Livestock Research for Rural Development., 2012; 24, Article\#35. http://www.lrrd.org//rrd24/

2/dutt24035.htm.

Githigia, S. M., Thamsborg, S. M., Munyua, W. K. and Maingi, N. 2001. Impact of gastrointestinal helminths on production in goats in Kenya. Small Ruminant Research, 42: 21-29.

Gregory, L., Yoshihara, E. and Silva, L. K. F. 2017. Anthelmintic effects of dried ground banana plant leaves (musa spp.) Fed to sheep artificially infected with Haemonchus contortus and Trichostrongylus colubriformis. African Journal of Traditional, Complementary and Alternative Medicine, 14(1): 138-144.

Gujja, S., Terrill, T. H., Mosjidis, J. A., Miller, J. E., Mechineni, A., Kommuru, D. S., Shaik, S. A., Lambert, B. D., Cherry, N. M. and Burke, J. M. 2013. Effect of supplemental Sericea lespedeza leaf meal pellets on gastrointestinal nematode infection in grazing goats. Journal of Veterinary Parasitology, 191: 51-58.

Heckendorn, F. 2007. The control of gastrointestinal sheep nematodes with tanniferous forage plants Dissertation for the degree, Doctor of Science, Swiss Federal Institute of Technology, Zurich.

Hoste, H., Martinez-Ortiz-De-Montellano, C., Manolaraki, F., Brunet, S., OjedaRobertos, N., Fourquaux, I., TorresAcosta, J. F. J. and Sandoval-Castro, C. A. 2012. Direct and indirect effects of bioactive tannin-rich tropical and temperate legumes against nematode infections. Veterinary Parasitology, 186: 18-27.

Iqbal, Z., Sarwar, M., Jabbar, A., Ahmed, S., Nisa, M., Sajid, M. S., Khan, M. N., Mufti K. A. and Yaseen, M. 2007. Direct and indirect anthelmintic effects of condensed tannins in sheep. Veterinary Parasitology, 144: 125-131.

Joshi, B. R., Kommuru, D. S., Terrill, T. H., Mosjidisc, J. A., Burke, J. M., Shakya, K. P. and Miller, J. E. 2011. Effect of feeding Sericea lespedeza leaf meal in goats experimentally infected with Haemonchus contortus. Journal of Veterinary Parasitology, 178: 192-197.

Mangan, J. L. 1988. Nutritional Effects of Tannins in Animal Feeds. Nutrition Research Reviews, 1(1): 209 - 231.

Manolaraki, F., Sotoraki, S., Stefanakis, A., Skampardonis, V., Volanis, M. and Hoste, H. 2010. Anthelmintic activity of some 
Mediterranean browse plants against parasitic nematodes. Veterinary Parasitology, 137: 685-696.

Moore, D. A., Terrill, T. H., Kouakou, B., Shaik, S. A., Mosjidis, J. A., Miller, J. E., Vanguru, M., Kannan, G. and Burke, J. M. 2008. The effects of feeding Sericea lespedeza hay on growth rate of goats naturally infected with gastrointestinal nematodes. Journal of Animal Science, 86: 2328-2337.

Murata, H., Shimada, N. and Yoshika, M. 2004. Current research on acute phase proteins in veterinary diagnosis: An overview. Veterinary Journal, 168: 28-40.

Netpana, N., Wanapa, M., Poungchompu, O. and Toburan, W. 2001. Effect of condensed tannins in cassava hay on fecal parasitic egg counts in swamp buffaloes and cattle. Proceedings International Workshop on Current Research and Development on Use of Cassava as Animal Feed, Khon Kaen University, Thailand. pp. 41-43.

Novobilský, A., Mueller-Harvey, I. and Thamsborg, S. M. 2011. Condensed tannins act against cattle nematodes. Veterinary Parasitology, 182: 213-220.

Olafadehan, O. A. 2011. Changes in haematological and biochemical diagnostic parameters of Red Sokoto goats fed tannin-rich Pterocarpus erinaceus forage diets. Vet. Arh., 81:471-483.

Olafadehan, O. A., Adewumi, M. K. and Okunade, S. A. 2014. Effects of feeding tannincontaining forage in varying proportion with concentrate on the voluntary intake, haematological and biochemical indices of goats. Trakia Journal of Science, 1:73-81.

Pan, S. and Maitra, D. N. 1992. Rumen metabolism of protein treated with salseed tannins or tannic acid. Veterinary Parasitology, 53: 67-74.

Pathak, A. K. and Tiwari, S. P. 2013. Effect of high plane of nutrition on the performance of Haemonchus contortus infected kids. Veterinary World, 6: 22-26.

Roepstorff A and Nansen P 1998. Epidemiology, diagnosis and control of helminth parasites of swine, FAO Animal Health Mnual, Rome.

Shaik, S. A., Terrill, T. H., Miller, J. E., Kouakou, B., Kannan, G. and Kaplan, R. M. 2006. Sericea lespedeza hay as a natural deworming agent against gastrointestinal nematode infection in goats. Veterinary Parasitology, 139: 150-157.

Sharma, D. K., Chauhan, P. P. S. and Agarwal, R. D. 2001. Changes in the levels of serum enzymes and total protein during experimental haemonchosis in Barbari goats. Small Ruminant Research, 42:119123.

Snedecor, G. W. and Cochran, W. G. 1994. Statistical methods. 8th ed., East West Press Pvt. Ltd., New Delhi.

Wang, Y., Waghorn, G. C., McNabb, W. C., Barry, T. N., Hedley, M. and Shelton, I. 1996. Effect of condensed tannins in Lotus corniculatus upon the digestion of methionine and cystine in the small intestine of sheep. Journal of Agricultural Science (Cambridge), 127: 413-421.

\section{How to cite this article:}

Sireesha, K., Ch. Venkata Seshaiah, K. Sudhakar, D. S. Kumar and Vinoo, R. 2021. Effect of Condensed Tannin Feeding on Serum Biochemical Profile and Faecal Egg Count in Nellore Brown Ewes. Int.J.Curr.Microbiol.App.Sci. 10(05): 358-367. doi: https://doi.org/10.20546/ijcmas.2021.1005.043 